\title{
Isolation of Uridine Requiring Variants in Chinese Hamster Cells
}

\author{
Toshihisa Kusano, Miwa Kato and Isao Yamane \\ Research Institute for Tuberculosis, Leprosy and Cancer, Tohoku University, \\ Sendai, Japan
}

Orotic aciduria is a rare autosomal recessive disease. The homozygous patients have megaloblastic anemia and pancytopenia. The patients also excrete large quantities of orotic acid in urine. Most and perhaps all of the disease symptoms respond to dietary supplementation of uridine. We undertook a search for auxotrophic variants in mammalian cells in vitro, as a possible model system for inherited human biochemical diseases. The present study reports on the induction and isolation of variant Chinese hamster cells requiring uridine for in vitro growth.

\section{MATERIALS AND METHODS}

The parental cell used was a Chinese hamster cell line V79. In culture, medium F12 (2) was used and supplemented with $10 \%$ nondialyzed or dialyzed calf serum (Flow Lab. Rockville, Md., USA). Dialysis was performed for 3 days in running tap water and for 1 day against three changes of $0.9 \%$ sodium chloride solution. The cells were plated in plastic petri dishes (Lux Scientific Corp., Thousand Oaks, Calif., USA) and incubated at $37^{\circ} \mathrm{C}$ in a humid atmosphere of $5 \% \mathrm{CO}_{2}$ in air. For isolation of variants requiring uridine, the cells were treated with $\mathrm{N}$-methyl- $\mathrm{N}$-nitrosoguanidine (MNNG) (Aldrich Co., Milwaukee, Wis., USA) at a concentration of $2 \mu \mathrm{g} / \mathrm{ml}$ for $24 \mathrm{~h}$. After treatment the cells were kept in uridine $\left(3 \times 10^{-5} \mathrm{M}\right)$ containing medium to assure mutation fixation for $48 \mathrm{~h}$. The cells were then trypsinized and appropriate inocula $\left(3-5 \times 10^{4}\right.$ cells per $6 \mathrm{~cm}$ petri dish) were deposited in uridine containing medium. After $24 \mathrm{~h}$, the medium was changed to medium F12 supplemented with $10 \%$ dialyzed calf serum, and the cells were kept under uridine deficient conditions for $24 \mathrm{~h}$ in the presence of 2,6, diaminopurine (Sigma Chemical Co., St. Louis, Missouri, USA), which was added to the medium at a concentration of $50 \mu \mathrm{g} / \mathrm{ml}$. Two weeks later the surviving colonies were isolated and tested for uridine requirements. Cell fusion was carried out with UV irradiated HVJ to test the complementation abilities of the different variant lines. The technique was essentially the same as that described by Okada (6). A mixture of the two variant cells was inoculated into replicated petri dished with $10^{5}$ cells per dish and cultured in uridine-deficient medium to follow-up genetic complementation. The growth of variants was observed in various concentrations of each intermediate metabolite of pyrimidine biosynthesis.

\section{RESULTS AND DISCUSSION}

For isolation of auxotrophic variants, it is important to kill the parental normal cells effectively and to selectively save the rare variants. Kao and Puck (3) devised the use of BUdR and fluorescent light for selection of biochemical mutants. Our attention was focused on selecting variants requiring pyrimidine nucleoside. BUdR is known as an analogue of thymidine and incorporates into cellular DNA instead of 


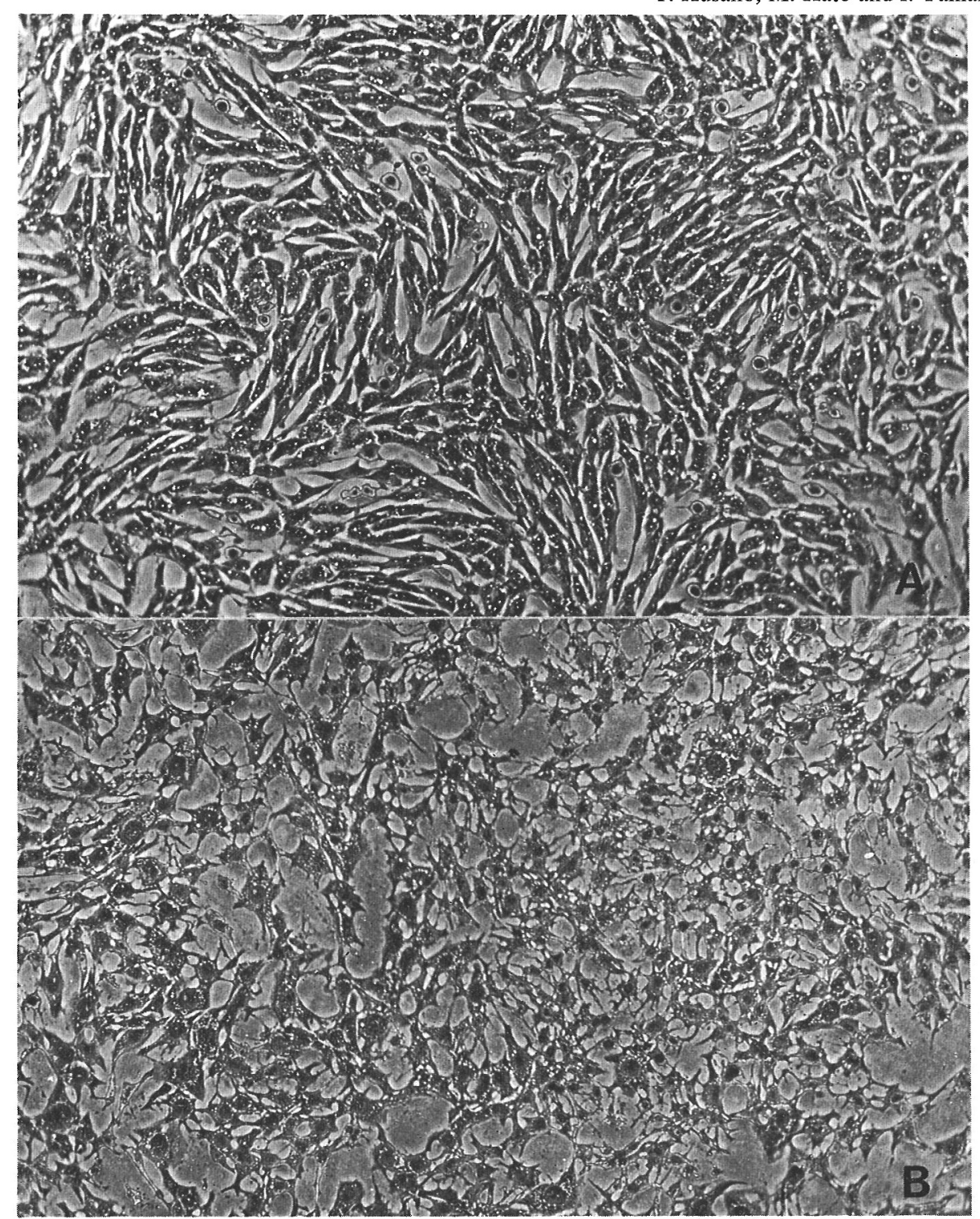

Fig. 1. Uridine requiring variant V79UR33. A, In the presence of uridine $\left(3 \times 10^{-5} \mathrm{M}\right)$.

$\mathrm{B}$, In the absence of uridine. $\times 200$.

thymidine, so it hampers the selection of thymidine-requiring cells. We used 2, 6, diaminopurine (DAP) as a selective agent of the variants. This agent is an adenine analogue and is supposed to kill cells after incorporation (5). The surviving fraction of growing Chinese hamster cells was less than $0.5 \%$ of the total population after treatment of cells with $30 \mu \mathrm{g} / \mathrm{ml}$ DAP for $24 \mathrm{~h}$. When our stock cultures of Chinese hamster cells were tested for pyrimidine nucleoside requirement, they were found to require thymidine but not uridine for growth. However, thymidine dependence decreased when the cell number of the deposition per plate increased. This suggested a leakage of the cellular thymidine pool into the culture medium. Thus far, two independent uridine-requiring variants were isolated by the DAP selection method. Alterations in 
TABLE 1. COMPLEMENTATION TEST BETWEEN URIDINE REQUIRING VARIANTS OF CHINESE HAMSTER CELLS V79

\begin{tabular}{lc}
\hline Variants & $\begin{array}{l}\text { Frequency of colony } \\
\text { formation in uridine- } \\
\text { deficient medium }\end{array}$ \\
\hline UR33 & $<1 \times 10^{-6}$ \\
UR52 & $<1 \times 10^{-6}$ \\
UR33 $\times$ UR52 & $3 \times 10^{-5}$ \\
\hline
\end{tabular}

the genetic characteristics were not evident in these variants. Morphologically the variants appeared fragile and showed many granules in the cytoplasm. When variant cells grown in the presence of uridine reached confluency, the medium had to be changed frequently or promptly subcultured to avoid deterioration and cell death. The parental cells survived for several days after confluency. The growth of the variants was slower than that of the wild type of cells. In the presence of $3 \times 10^{-5} \mathrm{M}$ uridine, the doubling times of the wild V79, variant UR33 and variant UR52 were $11.5,33.4$ and $21.5 \mathrm{~h}$, respectively. When they were cultured in medium F12 supplemented with $10 \%$ dialyzed calf serum and without uridine, the morphology and growth of the parental cells did not change but those of the variants were grossly affected. In one day, variant cells became flattened and ceased growth, as shown in Fig. 1. When small numbers of cells were plated at varied concentrations of uridine, the plating efficiency of the wild type V79 was not affected, but the variants grew poorly at a lower concentration of uridine. At concentrations of the uridine at $10^{-7} \mathrm{M}$ or lower, neither UR33 nor UR52 formed colonies; at $10^{-6} \mathrm{M}$ plating efficiencies were $12 \%$ and $23 \%$, respectively; at both $10^{-5} \mathrm{M}$ and $10^{-4} \mathrm{M}, 50 \%$ and $81 \%$, respectively; and at $10^{-3} \mathrm{M}, 60 \%$ and $51 \%$, respectively. The plating efficiency of the wild-type V79 was about $85 \%$.

Spontaneous reversion occurred at the rate of less than $4 \times 10^{-7}$ for variant UR33 and at less than $1 \times 10^{-7}$ for UR52. Revertants were induced at the rate of $2.4 \times 10^{-4}$ in UR33 when the cells were treated with MNNG $(2 \mu \mathrm{g} / \mathrm{ml})$ for $24 \mathrm{~h}$.

Two variants were co-cultivated after HVJ treatment of cells in uridine-deficient medium for the complementation test. No growing colony was formed in cultures of variants after HVJ treatment. However, in the mixed culture of the two variant cells, colonies were found at the rate of $3 \times 10^{-5}$, and this suggested that a genetic lesion occurred in each variant at different genetic loci (Table 1).

Krooth (4) studied the causes of orotic aciduria in skin fibroblast cell cultures from affected persons and he suggested that a genetic lesion might exist in the regulator gene (s). Cells cultured from the patients showed a loss of enzymatic activity in both orotidine-5'monophosphate pyrophosphorylase and orotidine-5'monophosphate decarboxylase, and indicated that uridine stimulated cellular growth. Variants UR33 and UR52 required uridine for growth, and to estimate the blocking site in the metabolic pathway, the variants were cultured in various concentrations of the intermediates of pyrimidine biosynthesis. Both variants grew in medium containing orotic acid, orotidine-5'monophosphate. Carbamylphosphate, carbamylaspartate or dihydroorotic acid failed to support the growth of both variants. These results suggest that both variants may have been affected functionally in the same gene, presumably the 
gene(s) which codes dihydroorotate dehydrogenase but at a different position because the cells grew after cell fusion.

We described here that the V79 cell developed uridine-requiring variants after MNNG treatment and the variants were selected by DAP. However, Chu, Sun and Chang (1) reported that they obtained a uridine-requiring variant using the BUdRblack light method.

Acknowledgment. This study was supported by a grant from the Japan Ministry of Education, Science and Culture.

\section{REFERENCES}

1. CHU, E.H.Y., N.C. Sun and C.C. CHANG. Induction of auxotrophic mutations by treatment of Chinese hamster cells with 5-bromodeoxyuridine and black light. Proc. Natl. Acad. Sci. USA 69, 3459-3463, 1972

2. HAm, R.G. Clonal growth of mammalian cells in a chemically defined synthetic medium. Proc. Natl. Acad. Sci. USA 53, 288-293, 1965

3. KAO, FA-TEN and T.T. PuCK. Genetics of somatic mammalian cells. VII. Induction and isolation of nutritional mutants in Chinese hamster cells. Proc. Natl. Acad. Sci. USA 60, 1275-1281, 1968

4. Krooth, R.S. Properties of diploid cell strains developed from patients with an inherited abnormality of uridine biosynthesis. Cold Spring Harbor Symp. 19, 189-212, 1964

5. KusAno, T., C. Long and H. Green. A new reduced human-mouse somatic cell hybrid containing the human gene for adenine phosphoribosyl transferase. Proc. Natl. Acad. Sci. USA 68, $82-86,1971$

6. OKADA, Y. The fusion of Ehrlich's tumor cells caused by HVJ virus in vitro. Biken J. 1, 103-110, 1958

(Received for publication, May 4, 1976) 